\title{
PROJEKTY HYBRYDOWE U PROGU PERSPEKTYWY FINANSOWEJ 2014-2020
}

\section{WSTĘP}

Rozwój w każdym z aspektów przejawów życia, zarówno społecznego, jak i gospodarczego, pozostaje nierozerwalnie związany z narastajacym pragnieniem posiadania i w konsekwencji zaspokajania różnorodnych potrzeb pojedynczej jednostki, jak również jednostek zrzeszających się w bardziej lub mniej zorganizowane w sposób formalny grupy, działające w celu osiagania zdefiniowanych założeń leżących u podstaw ich wyodrębnienia. Ewolucja otaczającej przestrzeni wynikająca z „wyścigu” każdego z interesariuszy (ang. stakeholders) w benchmarkingu naszych dążeń powoduje pojawianie się nieustannie narastających nieograniczonych potrzeb przy ograniczoności dostępności dóbr umożliwiających ich zaspokojenie. Współczesne społeczeństwa XXI w. stawiają na każdym kroku coraz to nowe, bardziej wymagające wyzwania przed potencjalnymi i docelowymi dostarczycielami dóbr i usług. Bez watpienia gospodarka w postaci czysto komercyjnej (sektor prywatny) opiera własne działania na reagowaniu, a w najlepszym wypadku oddziaływaniu i inicjowaniu, na zmienność trwale pozostającego w ruchu otoczenia. Wypełnienie luki powstałej z rozwijających się potrzeb jednostek przy niedostatku dóbr je zaspokajajaccych w połaczeniu z ekonomicznym celem funkcjonowania przedsiębiorstw (wzrost wartości) powodują względne wyrównywanie tych dysproporcji z wykorzystaniem szeroko rozumianej innowacyjności.

Odmienność celu powołania podmiotów sektora publicznego (państw i samorządów), działajaccych w idei m.in. zaspokajania potrzeb ogólnospołecznych, w obszarach otoczenia, wobec których sektor prywatny pozostaje bierny (nie dostrzega w nich źródeł korzyści) przy ograniczonej ilości i jakości posiadanych dóbr, w szczególności środków finansowych, stawia sferę publiczna w trudnej sytuacji, jednocześnie nie daje bodźców do rozwoju innowacyjności.

Kryzys gospodarczy z 2009 r. odcisnął w różnym stopniu piętno na całej gospodarce światowej i urzeczywistnił istnienie luki - dysproporcji potrzeb do zaspokajajaccych je dóbr - oraz obnażył słabość przede wszystkim nakręcanej fikcyjnej spirali możliwości rozwojowych przedsiębiorstw i wydatkowych państw. Podmioty sektora publicznego, intensyfikując wydatki, których tempo wzrostu w żaden sposób nie odpowiada tempu wzrostu potrzeb, dążąc do realizacji nałożonych na nie zadań, zostają zmuszone do pozyskiwania dodatkowych, zewnętrznych źródeł finansowania, najczęściej w postaci: pożyczek, kre- 
dytów, obligacji itd. Zaciaganie zobowiązań powodujące narastanie zadłużenia nie jest nieograniczone, lecz określone przez różnego rodzaju ramy w postaci wskaźników czy limitów wartościowych.

Kroczący postęp techniczno-technologiczny oraz w jego rezultacie - gospodarczy i społeczny nie hamują rozrostu kolejnych implikujacych się potrzeb. Podmioty publiczne osiagające poziom „sufitu” długu publicznego zostaja zmuszone do podejmowania działań związanych z reorganizacją systemu zarządzania w celu osiagania założonych efektów przy minimalnym nakładzie zasobów i transferowania wygenerowanych z nich nadwyżek w obszary odznaczające się deficytem, uzyskując oczekiwane rezultaty oscylujące między maksymalizacją lub minimalizacja zaspokajania potrzeb (dostarczania dóbr lub świadczenia usług). Tendencje postępu cywilizacyjnego to domena zarówno państw wysoko rozwiniętych, jak i krajów rozwijających się o wyraźnie zarysowanym opóźnieniu społeczno-gospodarczym, do których zalicza się i Polska po transformacji z 1989 r., kiedy to nastapiła deformacja struktur politycznych. Dysproporcja w rozwoju między Europą Zachodnią a państwami bloku wschodniego kontynentu, mimo usilnej pogoni w nadrabianiu różnic, stanowi element charakteryzujący trwały po dziś dzień podział na bogaty Zachód i biedną wschodnią część Europy.

Akcesja Polski do Unii Europejskiej postawiła przed państwem możliwości pozyskiwania dodatkowych bezzwrotnych źródeł finansowania, w szczególności w ramach planowanych projektów inwestycyjnych, mających służyć rozwiązaniu szerszego problemu społecznego w wymiarze strategicznym. Dofinansowanie $\mathrm{z}$ budżetu UE $\mathrm{w}$ formie środków finansowych pochodzących z funduszy, jako zasób kapitału, także posiada określone ograniczenia, choćby gwarantujace ich udzielenie, np. wkład własny podmiotu publicznego, spełnienie odpowiednich parametrów itd. Dodatkowym impulsem prorozwojowym dla Polski w ostatnich latach (2010-2012) była w pewnym stopniu współorganizacja wraz z Ukrainą przedsięwzięcia o randze międzynarodowej, tj. mistrzostw Europy w piłce nożnej (EURO 2012), a także schyłek perspektywy finansowej przypadającej na lata 2007-2013. W tych też latach obserwuje się wyraźny wzrost zadłużenia sektora publicznego, który poprzez dotychczasowy mechanizm zaciagania zobowiązań w pewnym stopniu zamyka przed sobą niekiedy możliwości zachowania trendu globalnego rozwoju, pomijając już fakt zagrożenia bieżącego utrzymania i kontynuacji działalności. Wrażliwość tych zjawisk jest istotna, gdyż w założeniach strategicznych państwa zostały wyznaczone predefiniowane kierunki rozwoju zapewniające wyrównanie poziomu życia z krajami Europy Zachodniej, obywatele zgłaszają określona, coraz to większa pod względem ilości, jakości i różnorodności pulę potrzeb do zaspokojenia, z kolei sfera publiczna w wyniku tych działań zostaje tym samym zmuszona do alternatywnych rozwiązań organizacyjnych.

$\mathrm{W}$ celu zapobieżenia zjawisku rozwierających się nożyc między nagromadzającymi się potrzebami a kurczącą się struktura portfela zasobów podmioty publiczne sięgają coraz częściej po rozwiązania do pewnego momentu niewykorzystywane, niepopularne, jednakże możliwe do zastosowania. Sektor publiczny poddany trudnej próbie stojących przed nim wyzwań wymagał - i nadal 
wymaga - gruntownej reorganizacji. Za jedno z rozwiązań uznano obserwację, analizę oraz „zassanie” wypraktykowanych w wieloletniej historii modeli systemów zarządzania funkcjonujących w sektorze prywatnym. Mechanizmem pozwalającym zespolić obszar wiedzy i doświadczenia świata komercyjnej gospodarki, dającym gwarancje osiagnnięcia skutecznie, oszczędnie i efektywnie określonego celu (np. projektu inwestycyjnego) przy zachowaniu optymalnego poziomu synergii międzysektorowej, jest zastosowanie formuły partnerstwa publiczno-prywatnego (PPP).

Zdolność skorzystania przez sektor publiczny z dofinansowania w ramach programów, jakie zostaną uruchomione w strukturze poszczególnych funduszy UE na lata 2014-2020, będzie możliwa ze wsparciem ze strony dodatkowego kapitału, mając na względzie poziom zadłużenia państwa oraz wielu samorządów u progu nowej perspektywy finansowej. Ważny warunek konieczny to zachowanie wartości zadłużenia na niezmienionym poziomie, zapewniajacym wypełnienie wymogów wynikających z przepisów prawa. Partnerstwo publiczno-prywatne przy spełnieniu określonych parametrów uzgodnień w zakresie zawartej umowy, np. przeniesie całości ryzyka na partnera prywatnego, daje możliwość uzyskania odpowiedniego zewnętrznego kapitału, który - wsparty dofinansowaniem z środków europejskich i gwarancją bezpieczeństwa ze strony podmiotu publicznego - umożliwia realizację przedsięwzięć nie tylko w skali mikro, ale i makro (np. regionów) przedmiotu działalności.

Narastajace zainteresowanie zarówno samą tematyką PPP w ujęciu instrumentalnym (źródło kapitału), jak i rozwiązań organizacyjnych (zarządzanie projektem, metody i sposób realizacji przedsięwzięcia, funkcjonowanie $\mathrm{w}$ fazie postrealizacji inwestycji) podmiotów sfery publicznej, a także podmiotów prywatnych u podstaw perspektywy finansowej na lata 2014-2020 oraz istniejaccych i prognozowanych problemów społeczno-ekonomicznym (średnioi długoterminowa strategia rozwoju kraju), stanowiły podstawę podjęcia się analizy charakteryzowanego przedmiotu rozważań - PPP z wykorzystaniem środków finansowych UE, tzw. projekty hybrydowe w Polsce z punktu widzenia studium ex post za lata 2007-2013 oraz planowanych ram działania ex ante.

Jednym z celów cząstkowych opracowania jest prezentacja efektów prowadzonej przez rząd polityki upowszechniania idei partnerstwa publiczno-prywatnego, w tym w korelacji z środkami z budżetu UE, na podstawie przeprowadzonej analizy podjętych lub planowanych projektów hybrydowych w Polsce w latach 2007-2013. Kolejne z celów cząstkowych to przedstawienie i ocena założeń kreowanej przez rząd strategii rozwoju państwa sformułowanej z uwzględnieniem zagregowanych informacji ex ante oraz przyjętych modeli wizji otoczenia społeczno-gospodarczego Polski w kontekście promowania PPP o strukturze hybrydowej. Ważnym elementem rozważań pozostają wytyczne Parlamentu Europejskiego ${ }^{1}$ w horyzoncie czasowym 2014-2020 względem dotychczas implikowanych rozwiązań na podstawie prawa polskiego i doświadczeń sektora publicznego. Za główny cel, na podstawie celów cząstkowych,

${ }^{1}$ Rozporządzenie Parlamentu Europejskiego i Rady UE nr 1303/2013 z 17 grudnia 2013 r., Dz. Urz. UE z 20 grudnia 2013 r. 
przyjęto zdefiniowanie istotnych działań, jakie rząd powinien podjąć, mając na uwadze realizację określonej polityki: wizji, misji i celów funkcjonowania państwa w świetle wartości dodanej dla sektora publicznego wynikającej $\mathrm{z}$ upowszechniania się wdrażania projektów hybrydowych PPP.

Zakres rozważań będzie obejmował funkcjonujące wytyczne Unii Europejskiej oraz prawa krajowego $\mathrm{w}$ odniesieniu do zastosowania partnerstwa publiczno-prywatnego w perspektywie finansowej 2014-2020, jak również praktyczne ujęcie realizowanych lub planowanych do wykonania projektów hybrydowych w latach 2007-2013, a więc praktycznie zakończonej perspektywy finansowej.

\section{WPROWADZENIE PARTNERSTWA PUBLICZNO-PRYWATNEGO W POLSCE}

Nieodłącznym przejawem kryzysu gospodarczego są postępujące procesy hamujące wzrost gospodarczy, co w konsekwencji powoduje ogólne pogorszenie sytuacji ekonomicznej. Istniejace ograniczenia i presja stanowią czynniki pobudzające pojawianie się nowych alternatywnych rozwiązań wychodzacych naprzeciw negatywnym zjawiskom gospodarczym. Wskutek kryzysów naftowych z lat siedemdziesiątych XX w. uformował się układ o charakterze partnerstwa publiczno-prywatnego, którego początki datuje się na lata osiemdziesiąte XX w. wraz z wdrożeniem pierwszych tego rodzaju przedsięwzięć w Stanach Zjednoczonych. Prawdziwy rozkwit współpracy podmiotów publicznych z partnerami sektora prywatnego nastapił tak naprawdę w latach dziewięćdziesiątych XX w., w szczególności w Wielkiej Brytanii, Irlandii czy Francji².

Szeroko rozumiane partnerstwo publiczno-prywatne było realizowane w Polsce już w pierwszej połowie lat dziewięćdziesiątych XX w., jednakże mimo tych pierwszych prób - często udanych - współpraca między podmiotami publicznymi a partnerami prywatnymi stanowiła rzadko stosowaną formę przedsięwzięcia. Najpoważniejszą przeszkodą w rozwinięciu się PPP był brak odpowiedniego prawodawstwa dodatkowo utrwalany kreowaną atmosfera polityczną wokół współpracy podmiotów publicznych z partnerami sektora prywatnego. Intensywny rozwój partnerstwa publiczno-prywatnego w Europie Zachodniej, w szczególności z początkiem XXI w., oraz przystapienie Polski do Unii Europejskiej przyczyniły się znacząco do uchwalenia ustawy z 28 lipca 2005 r. o partnerstwie publiczno-prywatnym ${ }^{3}$.

Bardzo ważnym impulsem do podjęcia przedmiotowej ustawy było również dostrzeżenie pozytywnych aspektów układu partnerskiego między podmiotami sektorów publicznego i prywatnego. W podstawowym założeniu ustawa o PPP miała stworzyć jednoznaczna podstawę prawną w przedmiotowym zakresie - ramy prawne współpracy - oraz upowszechnić tę formę kooperacji międzysektorowej. De facto wprowadzone ustawodawstwo nie uzdrowiło do-

${ }^{2}$ T. Skoczyński, Ustawa o partnerstwie publiczno-prywatnym. Komentarz, Lex, Warszawa 2011.

${ }^{3}$ Dz. U. Nr 169, poz. 1420 ze zm. 
tychczasowej sytuacji z uwagi na wymóg przeprowadzenia wielu kosztownych szczegółowych analiz przez podmiot publiczny oraz skomplikowany stopień procesu przygotowawczego do wszczęcia procedury wyboru partnera prywatnego. Czynnikiem hamującym rozwój PPP w Polsce było również narastające wykorzystywanie środków unijnych, w szczególności przez samorządy terytorialne najbardziej zainteresowane współpraca z partnerami prywatnymi, koncentrujace własne inwestycje na udział dofinansowania z funduszy UE, co w konsekwencji spowodowało brak realizacji projektów w formule partnerstwa publiczno-prywatnego w oparciu o ustawę z 2005 r. ${ }^{4}$

Historia partnerstwa publiczno-prywatnego w odniesieniu do niektórych państw członkowskich UE jest długa, z kolei w wypadku innych jego rozwój nastapił stosunkowo niedawno. W szczególności PPP nadano istotne znaczenie w tych państwach, w których występuje proces wyraźnego wzrostu gospodarczego. PPP stanowi niezwykle ważny instrument wsparcia w krajach podejmujacych starania o przystapienie do UE, a także stosunkowo niedawno włączonych do struktur UE, mających na celu reformę i poprawę infrastruktury oraz usług w kontekście dostosowania ich do norm unijnych. Podstawowe zadania dla sektora prywatnego w ramach układu partnerskiego zgodnie z wytycznymi Komisji Europejskiej to zapewnienie:

1) dodatkowego kapitału,

2) alternatywnych umiejętności w zakresie wdrażania i zarządzania,

3) wartości dodanej konsumentowi i ogółowi społeczeństwa,

4) lepszego określenia potrzeb i optymalnego wykorzystania zasobów ${ }^{5}$.

System prawny Unii Europejskiej reguluje problematykę partnerstwa publiczno-prywatnego tzw. prawem miękkim. Komisja Europejska nie zdecydowała się na scentralizowaną harmonizację przepisów, przyjmując z kolei szereg dokumentów o charakterze kierunkowym ${ }^{6}$. Wśród istotnych dokumentów obejmujących obszar PPP uwzględnia się:

- Dyrektywę nr 2004/18/WE Parlamentu Europejskiego i Rady z 31 marca 2004 r. w sprawie koordynacji procedur udzielania zamówień publicznych na roboty budowlane, dostawy i usługi ${ }^{7}$;

- Dyrektywę nr 2004/17/WE Parlamentu Europejskiego i Rady z 31 marca $2004 \mathrm{r}$. w sprawie koordynacji procedur udzielania zamówień przez podmioty działające w sektorach gospodarki wodnej, energetyki, transportu i usług pocztowych ${ }^{8}$;

4 Ibidem.

5 Wytyczne dotyczqce udanego partnerstwa publiczno-prywatnego, Komisja Europejska Dyrektoriat Regionalny ds. Polityki Regionalnej, Bruksela 2003, s. 2 i 3.

${ }^{6}$ B. Korbus, T. Srokosz, M. Wawrzyniak, Partnerstwo publiczno-prywatne. Poradnik, Urząd Zamówień Publicznych Departament Informacji, Edukacji i Analiz Systemowych, Warszawa 2010, s. 24.

7 Dz. Urz. UE L 134 z 30 kwietnia 2004 r., s. 114; Dz. Urz. UE Polskie wydanie specjalne rozdz. 06, t. 7 .

8 Dz. Urz. UE L 134 z 30 kwietnia 2004 r., s. 1, Dz. Urz. UE Polskie wydanie specjalne, rozdz. 06, t. 7 . 
- Komunikat Komisji dla Parlamentu Europejskiego, Rady, Europejskiego Komitetu Ekonomiczno-Społecznego oraz Komitetu Regionów z 19 listopada 2009 r. w sprawie zwiększania znaczenia partnerstw publiczno-prywatnych;

- Komunikat Komisji dla Parlamentu Europejskiego, Rady, Europejskiego Komitetu Ekonomiczno-Społecznego oraz Komitetu Regionów w sprawie partnerstw publiczno-prywatnych oraz prawa wspólnotowego dotyczącego zamówień publicznych i koncesji z 15 listopada 2005 r. ${ }^{10}$;

- Komunikat wyjaśniający Komisji w sprawie stosowania prawa wspólnotowego dotyczącego zamówień publicznych i koncesji w odniesieniu do zinstytucjonalizowanych partnerstw publiczno-prywatnych (ZPPP) z 5 lutego 2008 r. ${ }^{11}$

- Komunikat Komisji Europejskiej z 27 kwietnia 2000 r. w sprawie interpretacji przepisów dotyczących udzielenia koncesji na podstawie prawa unijnego ${ }^{12}$

- Wytyczne Komisji Europejskiej w sprawie udanego partnerstwa publiczno-prywatnego, styczeń 2003 r.;

- Rezolucję Parlamentu Europejskiego w sprawie partnerstw publiczno-prywatnych oraz prawa wspólnotowego w zakresie zamówień publicznych i koncesji z 26 października 2006 r.;

- Zielona księgę partnerstw publiczno-prywatnych i prawa wspólnotowego w zakresie zamówień publicznych i komisji, wydaną przez Komisję Europejska ${ }^{13} 30$ kwietnia 2004 r. $^{14}$

W perspektywie finansowej na lata 2014-2020 niezwykle ważnym dokumentem będzie Rozporządzenie Parlamentu Europejskiego i Rady (UE) nr 1303/2013 z 17 grudnia 2013 r., opublikowane w „Dzienniku Urzędowym Unii Europejskiej” z 20 grudnia 2013 r., wyznaczające określone ramy projektów hybrydowych, jednakże i tak nie stanowią one stricte unormowań w zakresie partnerstwa publiczno-prywatnego, pozostawiając swobodę kształtowania systemów przez instytucję zarządzające funduszami UE.

Zakres uregulowań krajowych dotyczących partnerstwa publiczno-prywatnego w sposób znacznie bardziej precyzyjny formułuje otoczenie i zasady, w zgodzie z którymi należy postępować, aby z jednej strony nie naruszyć prawa, z drugiej - przeprowadzić całą procedurę w sposób najbardziej efektywny dla podmiotu publicznego. Ustawa o PPP z 2005 r., będąca poprzedniczką konwencji ram funkcjonowania układu partnerskiego między sektorami, została zastapiona ustawa z 19 grudnia 2008 r. o partnerstwie publiczno-prywatnym ${ }^{15}$, uzupełnioną ustawa z 9 stycznia 2009 r. o koncesji na roboty budowla-

${ }^{9} \mathrm{COM}(2009), 615$.

${ }^{10} \mathrm{COM}(2005), 569$.

${ }^{11}$ Dz. Urz. UE C 91 z 12 kwietnia 2008 r., s. 4.

${ }^{12}$ Dz. Urz. UE C 121/02 z 27 kwietnia 2000 r., s. 14-21.

${ }^{13}$ COM (2004), 327, Bruksela 2004 r.

${ }^{14}$ Partnerstwo publiczno-prywatne krok po kroku, w ramach projektu: NOVUS - program rozwoju administracji samorządowej Warszawy, Poznania, Lublina, Ełku i Łodzi, Warszawa 2011, s. 10 i 11.

${ }^{15}$ Dz. U. 2009. Nr 19, poz. 100. 
ne lub usługi ${ }^{16}$. W odniesieniu do ustawy o koncesji na roboty budowlane, o ile to narzędzie zostało już wdrożone w polskim prawie od $2004 \mathrm{r}$. w ramach prawa zamówień publicznych, o tyle instrument partnerstwa w postaci koncesji na usługi stanowił nowy element polskiej wykładni prawa. Ustawa o koncesji z 2009 r. obejmowała jednocześnie każdą z form koncesjonowania realizacji zadań publicznych w jednym akcie prawnym. Oba akty prawne, które weszły w życie z końcem lutego 2009 r., miały na celu ułatwić realizacje zadań publicznych na zasadzie kooperacji sektorów (publicznego i prywatnego) oraz upowszechnić wykorzystanie tego typu modelu finansowania przedsięwzięć infrastrukturalnych w Polsce ${ }^{17}$.

\section{Schemat 1}

Ramy prawne partnerstwa publiczno-prywatnego w Polsce

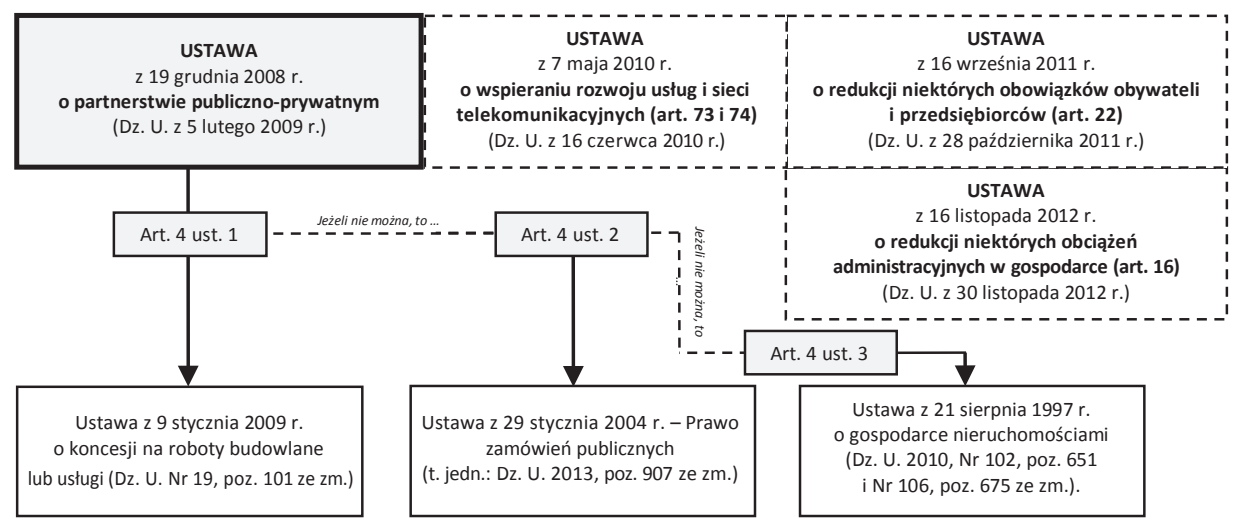

Źródło: opracowanie własne według stanu prawnego na dzień 15 stycznia 2014 r.

W odróżnieniu od niektórych państw polski ustawodawca nie wyznaczył wprost organu publicznego odpowiedzialnego za wykładnię oraz prawidłowe stosowanie ustaw o PPP oraz koncesji na roboty budowlane i usługi. Zgodnie z obowiąującym systemem prawa rozstrzyganie zagadnień prawnych w określonych wypadkach każdorazowo będzie kompetencją poszczególnych organów, mianowicie w przypadku koncesji - sądów administracyjnych, z kolei w stosunku do PPP uregulowanego prawem zamówień publicznych (tj. w sytuacji gdy większa część ryzyka ekonomicznego przedsięwzięcia pozostaje po stronie publicznej), odpowiednio, Krajowej Izby Odwoławczej oraz sądów powszechnych, a w przedmiocie ogólnych i systemowych interpretacji, jak również indywidualnych decyzji - Prezesa Urzędu Zamówień Publicznych ${ }^{18}$.

\footnotetext{
16 Dz. U. 2009, Nr 19, poz. 101 i Nr 157, poz. 1241.

17 B. Korbus, T. Srokosz, M. Wawrzyniak, op. cit., s. 11.

18 Ibidem, s. 13 i 14.
} 
W zakresie upowszechniania i promowania formuły partnerstwa publiczno-prywatnego oraz dokonywania analiz i ocen funkcjonowania współpracy sektorów publicznego i prywatnego, w tym także określania stanu i perspektyw finansowego zaangażowania podmiotów prywatnych w modele PPP, odpowiedzialność za realizację tych zadań ponosi minister właściwy ds. gospodarki ${ }^{19}$.

Unijne prawodawstwo nie precyzuje pojęcia partnerstwa publiczno-prywatnego, jednakże w polskiej nomenklaturze prawnej sformułowano definicję PPP, uznając, że jej podstawowym celem jest: „[...] wspólna realizacja przedsięwzięcia oparta na podziale zadań i ryzyka pomiędzy podmiotem publicznym i partnerem prywatnym" ${ }^{20}$. Ustawodawca, precyzując charakter formuły PPP, uszczegółowił podmioty nawiązujące stosunek partnerski, tj.:

1) podmiot publiczny, którym jest:

a) jednostka sektora finansów publicznych;

b) inna osoba prawna, utworzona w szczególnym celu zaspokajania po-

trzeb powszechnie dostępnych, niemajacca charakteru przemysłowego ani handlowego, w wypadku gdy jednostki sektora finansów publicznych pojedynczo lub wspólnie, bezpośrednio lub pośrednio przez inny podmiot:

- finansuja ja w ponad $50 \%$ lub

- posiadaja ponad połowę udziałów albo akcji, lub

- sprawuja nadzór nad organem zarządzajacym, lub

- maja prawo do powoływania ponad połowy składu organu nadzorczego lub zarządzającego;

c) związek jednostki sektora finansów publicznych i innej osoby prawnej;

2) partner prywatny rozumiany syntetycznie jako przedsiębiorca lub przedsiębiorca zagraniczny ${ }^{21}$.

W ustawie o PPP zostało zdefiniowane pojęcie przedsięwzięcia charakteryzowanego w kategoriach:

1) budowy lub remontu obiektu budowlanego,

2) świadczenia usług,

3) wykonania dzieła, w szczególności wyposażenia składnika majątkowego w urządzenia podwyższające jego wartość lub użyteczność,

4) inne świadczenie - połączone z utrzymaniem lub zarządzaniem składnikiem majątkowym, który jest wykorzystywany do realizacji przedsięwzięcia publiczno-prywatnego lub jest z nim związany ${ }^{22}$.

Ze względu na brak w przedmiotowej ustawie definicji ryzyka można skorzystać z określenia tego pojęcia w dokumencie Komisji Europejskiej z 2003 r.: „Wytyczne dotyczace udanego partnerstwa publiczno-prywatnego”. W ramach tego dokumentu ryzyko jest rozumiane jako: ,[...] jakikolwiek czynnik, zdarzenie lub wpływ, który zagraża korzystnemu zakończeniu projektu w kontekście czasu, kosztu lub jakości”. Z punktu widzenia efektywności przedsięwzięcia

19 Ustawa z 19 grudnia 2008 r. o partnerstwie publiczno-prywatnym (Dz. U. 2009, Nr 19, poz. 100 ze zm.), art. 3.

${ }^{20}$ Ibidem, art. 1 ust. 2.

21 Ibidem, art. 2 pkt 1 i 2 .

22 Ibidem, art. 2 pkt 4. 
należy przyjąć zasadę, że ryzyko powinno być transferowane na stronę zdolna sobie z nim poradzić, która jest w stanie najlepiej sobie z nim poradziće ${ }^{23}$.

Rodzaj przedsięwzięcia w formule partnerstwa publiczno-prywatnego warunkuje najbardziej efektywną strukturę układu dla modelu zaangażowania partnera prywatnego w określona inwestycję (projektowanie, budowa, finansowanie, eksploatacja, przejmowanie i przekazanie). Wśród najczęściej stosowanych w praktyce odmian PPP wyróżnia się model:

1) BOT (ang. build-operate-transfer) - buduj-eksploatuj-przekaz;;

2) DBOT (ang. design-build-operate-transfer) - projektuj-buduj-eksploatuj-przekaż;

3) BOOT (ang. build-own-operate-transfer) - buduj-przejmuj-eksploatujprzekaz;

4) BOO (ang. build-own-operate) - buduj-przejmuj-eksploatuj;

5) DBFO (ang. design-build-finance-operate) - projektuj-buduj-finansujeksploatuj ${ }^{24}$.

Przedsięwzięcia realizowane z wykorzystaniem współpracy sektorów publicznego i prywatnego w trybie PPP pozwalają uzyskać następujące korzyści:

1) przeprowadzenie projektów przy ograniczonej dostępności kapitału podmiotu publicznego,

2) większa efektywność procesu implikacji oraz zarządzania projektem,

3) transfer ryzyka do podmiotu zdolnego do poradzenia sobie z nim (alokacja),

4) optymalizacja kosztów całkowitych projektu,

5) większa możliwość generowania dodatkowych przychodów,

6) szerszy zakres oraz lepsza jakość usług publicznych,

7) usprawnienie działania administracji publicznej,

8) wdrożenie mechanizmów konkurencji w świadczeniu usług publicznych $^{25}$.

W ramach polskiego prawodawstwa wprost wyodrębniono zapis upoważniający do skorzystania z dofinansowywania ze środków budżetowych Unii Europejskiej przy realizacji projektów z wykorzystaniem partnerstwa publiczno-prywatnego, określanych mianem projektów hybrydowych, a więc łaczących finansowanie prywatne i ze środków dotacyjnych, co również wyjaśniają Wytyczne Komisji Europejskiej. Na mocy art. 32 ustawy z 2008 r. o partnerstwie publiczno-prywatnym wskazano, że: „W ramach programu operacyjnego dofinansowane mogą być także projekty, [...], realizowane w formie partnerstwa publiczno-prywatnego, na podstawie ustawy z 19 grudnia 2008 r. o partnerstwie publiczno-prywatnym (Dz. U. 2009, Nr 19, poz. 100)" (w art. 28 ustawy z 6 grudnia 2006 r. o zasadach prowadzenia polityki rozwoju dodano ust. 9).

Zasady dotyczące funduszy strukturalnych dopuszczają możliwość uznania podmiotu prywatnego za beneficjenta, jednakże beneficjenci muszą być także inicjatorami projektu, co oznacza w praktyce, że projekty o charakterze

\footnotetext{
${ }^{23}$ Wytyczne..., s. 63.

${ }^{24}$ B. Korbus, T. Srokosz, M. Wawrzyniak, op. cit., s. 8.

${ }^{25}$ Ibidem, s. 24.
} 
prywatno-prywatnym moga funkcjonować łącznie z uczestnictwem prywatnych beneficjentów, $\mathrm{z}$ kolei $\mathrm{w}$ ramach partnerstwa publiczno-prywatnego, to podmioty publiczne mogą być wyłącznie inicjatorem projektu, a więc i beneficjentami. Podmiot publiczny jest stroną zdolna do podpisania wniosku o dotację oraz uprawniona do otrzymania środków finansowych po udokumentowaniu wydatków ${ }^{26}$.

Ramy legislacyjne funkcjonowania PPP w Polsce, mimo ich ustrukturyzowanego systemu nakazów, zakazów i wytycznych - również w zakresie dofinansowania przedsięwzięć z środków unijnych - wraz z podmiotem odpowiedzialnym za nadzór nad prawidłowym i zgodnym stosowaniem prawa, rozpowszechnianiem formuły partnerskiej oraz analizą i oceną efektów procesów wdrażania, nie dają w pełni podstaw do sformułowania pozytywnej oceny stworzonego przez ustrój polityczny otoczenia zachęcajacego zarówno podmioty publiczne, jak i podmioty prywatne, do kreowania układów partnerskich na potrzeby realizacji przedsięwzięć o charakterze publicznym.

\section{PROJEKTY HYBRYDOWE W POLSCE W PERSPEKTYWIE FINANSOWEJ 2007-2013}

„Wpływ budżetu UE można wzmocnić tym bardziej, im większe jest jego wykorzystanie w celu wsparcia finansowego inwestycji strategicznych o najwyższej europejskiej wartości dodanej. Innowacyjne instrumenty finansowe mogą zapewnić ważne źródło nowego strumienia finansowania inwestycji strategicznych. Normą dla projektów o długoterminowym potencjale handlowym powinno być wykorzystanie środków UE we współpracy z sektorem prywatnym [wyr. - B.E.] i bankowym”27.

Szacowana liczba kontraktów PPP wpisanych w UE od 2007 r. i zamkniętych finansowo do $2010 \mathrm{r}$. kształtuje się na poziomie 350 nowych projektów z łączną wartością sięgająca prawie 70 miliardów. Od 2006 r. rynek PPP w Europie jeszcze bardziej zdywersyfikował się pod względem krajów oraz sektorów, jednakże niekwestionowanym liderem w kwestii ilości wdrażanych projektów w Europie pozostawała Wielka Brytania ze zróżnicowanym portfelem inwestycji sektorowych (zdrowie, edukacja, transport itd.). Głównym sektorem w zakresie przedsięwzięć we wszystkich państwach zjednoczonej Europy jest bez watpienia transport. W trakcie kryzysu finansowego rynek partnerstwa publiczno-prywatnego w Europie uległ znaczącemu skurczeniu w większości krajów i sektorów. Intensyfikacja realizacji małych projektów wyraźnie wpłynęła na całkowitą wartość przedsięwzięć PPP i zwiększyła ilość

${ }^{26}$ Wykorzystanie funduszy UE $w$ PPP - omówienie metodologii i rozpoczęcie debaty o przyszłości, Wydawnictwo Europejskiego Centrum Wiedzy PPP (ang. European PPP Expertise Centre), Warszawa 2011, s. 12.

${ }^{27}$ Komunikat Komisji skierowany do Parlamentu Europejskiego, Rady, Europejskiego Komitetu Ekonomiczno-Społecznego, Komitetu Regionów i Parlamentów narodowych - Przegląd budżetu UE z 19 października 2010 r., Warszawa 2010, s. 22. 
negatywnie rozstrzygniętych postępowań o wybór partnera (wartość transakcji PPP w 2009 r. zmniejszyła się o 50\% w porównaniu z 2007) ${ }^{28}$.

Wzajemne zestawienie wiedzy, doświadczenia i kapitału podmiotu publicznego funkcjonującego w sferze nieograniczonej „chmury” oczekiwań społecznych z podmiotem prywatnym działającym, w założeniu, w celu zaspokajania określonej wiązki potrzeb i osiagania planowanych korzyści ekonomicznych, dodatkowo z udziałem finansowego wsparcia w postaci funduszy UE, powoduje przy tak rozbudowanej sieci powiązań istnienie zarówno zalet, jak i wad takiego układu, co zostało przedstawione w tabeli 1.

Tabela 1

Zalety i wady projektu hybrydowego PPP

\begin{tabular}{|c|c|}
\hline \multicolumn{2}{|c|}{ Projekt hybrydowy PPP } \\
\hline Zalety & Wady \\
\hline $\begin{array}{l}\text { - Skuteczna współpraca między sektorem } \\
\text { publicznym i prywatnym }\end{array}$ & $\begin{array}{l}\text { - Dotacje nie wymuszają efektywności eko- } \\
\text { nomicznej przedsięwzięć, jak w wypadku } \\
\text { innych źródeł finansowania (zwrotnych } \\
\text { źródeł finansowania) }\end{array}$ \\
\hline $\begin{array}{l}\text { - Poprawa efektywności i wskaźnika (value } \\
\text { for money) }\end{array}$ & $\begin{array}{l}\text { - Zagrożenie uzależnienia projektu od wy- } \\
\text { magań oraz celów podmiotu dotującego, } \\
\text { co może skutkować przedłożeniem jego } \\
\text { wymogów ponad inne korzystniejsze roz- } \\
\text { wiazzania, w tym również z udziałem form } \\
\text { finansowania komercyjnego, z kolei w kon- } \\
\text { sekwencji istnieje groźba zmniejszenia } \\
\text { efektywności całego przedsięwzięcia wraz } \\
\text { z utratą korzyści wynikających z wdroże- } \\
\text { nia PPP }\end{array}$ \\
\hline $\begin{array}{l}\text { - Wiarygodność projektu względem innych } \\
\text { podmiotów, w szczególności instytucji } \\
\text { finansujących }\end{array}$ & $\begin{array}{l}\text { - Umożliwienie łatwego dostępu do dotacji } \\
\text { może doprowadzić do sytuacji, w której } \\
\text { podmioty publiczne zamiast dążyć do po- } \\
\text { szukiwania efektywnych i alternatywnych, } \\
\text { w opozycji do dotacji, źródeł finansowania } \\
\text { przedsięwzięć ograniczą się do optymaliza- } \\
\text { cji własnych kryteriów w sposób uzależnio- } \\
\text { ny i gwarantujący uzyskanie dotacji, rów- } \\
\text { nież kosztem efektywności ekonomicznej } \\
\text { przedsięwzięcia }\end{array}$ \\
\hline $\begin{array}{l}\text { - Pokrycie kosztów wstępnych studiów pro- } \\
\text { jektu i wsparcie instytucjonalne ze strony } \\
\text { UE }\end{array}$ & $\begin{array}{l}\text { - Złożona i przewlekła procedura biurokra- } \\
\text { tyczna związana z pozyskaniem i wyko- } \\
\text { rzystaniem dotacji obejmująca znacząca } \\
\text { wartość kosztów działań }\end{array}$ \\
\hline
\end{tabular}

28 A. Kappeler, M. Nemoz, Public Private Partnerships in Europe - before and during the Recent Financial Crisis, Economic and Financial Report 2010/04, European Investment Bank, 2010, s. 28. 


\begin{tabular}{|c|c|}
\hline \multicolumn{2}{|c|}{ Projekt hybrydowy PPP } \\
\hline Zalety & Wady \\
\hline - Dźwignia finansowa umożliwiająca zmniej- & \\
szenie ogólnych kosztów przedsięwzięcia & \\
lub odpowiednio zwiększenie strumienia & \\
dochodu (dotacje) & \\
- Gwarancja finansowa umożliwiająca zarzą- & \\
dzanie ryzykiem finansowym (dotacje) & \\
\hline
\end{tabular}

Źródło: opracowanie własne na podstawie B. Korbus, T. Srokosz, M. Wawrzyniak, Partnerstwo publiczno-prywatne. Poradnik, Urząd Zamówień Publicznych Departament Informacji, Edukacji i Analiz Systemowych, Warszawa 2010, s. 145 i 146.

Wbrew możliwościom wykorzystywania funduszy Unii Europejskiej na potrzeby partnerstwa publiczno-prywatnego, od $2007 \mathrm{r}$. zrealizowano niezwykle mało projektów o zespolonej funkcji źródeł finansowania (UE i PPP), co jest konsekwencją istniejących programów dotacji związanych z dopłatami do kapitału, a to z kolei nie sprzyja zastosowaniu PPP. W celu rozwiązania tego problemu Komisja UE wraz z EPEC (European PPP Expertise Centre) podjęła prace dążące do ułatwienia łączenia PPP z funduszami strukturalnymi przed przygotowaniami do następnego okresu budżetowego UE i perspektywy finansowej 2014-2020. Korzyści wynikające $\mathrm{z}$ formuły partnerstwa publiczno-prywatnego i jego podejścia odnoszącego się do całkowitego okresu użytkowania (ang. whole-life approach) w stosunku do koncepcji projektu, jak również jego wdrażania i zarządzania nim, może, a wręcz powinno, znaleźć jeszcze szersze uznanie polityczne ${ }^{29}$.

\section{Schemat 2}

Najistotniejsze trudności organizacyjne związane z procesem ubiegania się o dotację z funduszy strukturalnych

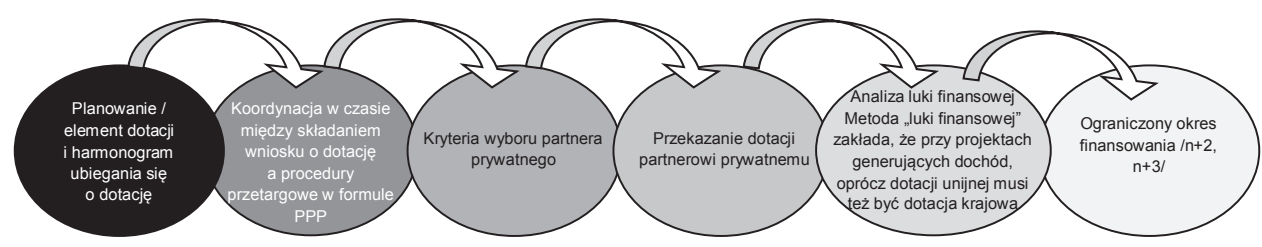

Źródło: opracowanie własne na podstawie Wykorzystanie funduszy UE w PPP-omówienie metodologii i rozpoczęcie debaty o przyszłości, Wydawnictwo Europejskiego Centrum Wiedzy PPP, Warszawa 2011, s. 10-14.

Schemat 2 stanowi syntetyczną prezentację najistotniejszych trudności organizacyjnych związanych z procesem ubiegania się o dotację z funduszy strukturalnych, wpływających negatywnie na nawiązywanie współpracy $\mathrm{w}$ formule partnerstwa publiczno-prywatnego.

${ }^{29}$ Wykorzystanie funduszy..., op. cit., s. 5. 
Modele projektów hybrydowych zakładają cztery sposoby łączenia funduszy strukturalnych z finansowaniem prywatnym w projektach PPP (modele sa z zasady wykonalne i były wykorzystywane w państwach członkowskich, chociaż różnią się ze względu na stopień trudności ich realizacji), a mianowicie:

1. Dotację stanowiąca wkład w ramach nakładów publicznych - dotacja jest wykorzystywana bezpośrednio jako częściowe sfinansowanie kosztów inwestycyjnych określonych aktywów, z kolei opłaty za dostępność lub pobierane od użytkowników są w konsekwencji niższe (model niedostosowany do reguł funkcjonowania PPP).

2. Współfinansowanie równoległe $\mathrm{w}$ założeniu jest związane $\mathrm{z}$ podzieleniem obiektu infrastruktury lub programu na minimum dwie wyodrębnione części, w ramach których jedna jest finansowana ze środków publicznych, także z dotacji UE, na podstawie procedury zamówień publicznych, druga zaś z wykorzystaniem instrumentu PPP. Każdy z elementów projektu w następnym etapie może być eksploatowany łącznie w jednej koncesji, jednakże opłaty za dostępność lub uiszczane przez użytkowników sa niższe aniżeli w wypadku pełnej procedury PZP w modelu PPP.

3. Dotacje pozostające środkiem częściowego finansowania opłat za dostępność lub opłat użytkownika, co jest klasycznym modelem powiązania dotacji z finansowaniem prywatnym (model w pełni dostosowuje się do fundamentalnej zasad PPP, zgodnie z którą transfer środków do sektora prywatnego powinien wiązać się ze świadczonymi usługami, a nie poniesionymi kosztami, jednakże w praktyce jest on nadzwyczaj trudny do wykorzystania z uwagi na zasadę związana z funduszami strukturalnymi, tj. $\mathrm{n}+2$ ).

4. Model funduszu inwestycyjnego, który zakłada powiązanie funduszy strukturalnych zarówno ze środkami publicznymi, jak i prywatnymi w ramach funduszu inwestycyjnego, inwestującego w portfolio projektów partnerstwa publiczno-prywatnego (lub innych) z wykorzystaniem instrumentów zwrotnych. Podstawową zaletą modelu funduszu inwestycyjnego jest to, że zainwestowane fundusze strukturalne są odzyskiwane, z kolei kapitał oraz zysk mogą zostać reinwestowane (np. model JESSICA, w którym fundusze strukturalne zostają powierzone funduszom rozwoju obszarów miejskich, niekiedy za pośrednictwem funduszu holdingowego/powierniczego) ${ }^{30}$.

W polskiej przestrzeni gospodarczej realizacja inwestycji o charakterze publicznym (zaspokajania potrzeb w zakresie dostarczania dóbr i/lub świadczenia usług publicznych), w formule współpracy między sektorami - publicznym i prywatnym - jest zjawiskiem de facto zainicjowanym od strony praktycznej, mimo wcześniejszych uregulowań, dopiero w 2009 r. Na chwilę obecną stworzony „inkubator” ram prawnych, począwszy od ustawy o PPP z 2005 r., wsparty procesami upowszechniania i promowania idei kooperacji podmiotów publicznych z prywatnymi partnerami, a także przekonywania do dystrybuowania środków finansowych zakumulowanego kapitału komercyjnego w kierunku działalności publicznej nie wykreował otoczenia, w którym przedsięwzięcia w układzie partnerstwa publiczno-prywatnego rozwijałyby się w znaczącej skali w stosunku do inwestycji realizowanych metodą tradycyjną. Ilość

${ }^{30}$ Ibidem, s. 12-14. 
zidentyfikowanych projektów w modelu finansowania z wykorzystaniem PPP w Polsce do końca 2013 r. pozostaje niewielka, w tym dość duża część z nich to przedsięwzięcia: planowane, na etapie procedur związanych z wyborem partnera lub zakończone niepowodzeniem. W ramach całkowitej liczby projektów PPP rzadko występują rozwiązania hybrydowe (PPP i środki finansowe UE), uznane za bardzo skomplikowane w strukturze modelowej, jednakże dające niewspółmiernie wiele korzyści - przede wszystkim dodatni efekt w zakresie wsparcia finansowego.

Na podstawie informacji zaprezentowanych na stronie portalu internetowego Platformy Partnerstwa Publiczno-Prywatnego powołanej z inicjatywy Ministra Rozwoju Regionalnego, a opracowanej przez Departament Wsparcia Projektów Partnerstwa Publiczno-Prywatnego, według stanu na październik 2013 r., zostało zidentyfikowanych w Polsce 19 projektów hybrydowych pozostających na różnym etapie realizacji, o łącznej wartości: 4068,23 mln zł, przy czym wartość dofinansowania z Unii Europejskiej wynosi: 2553,49 mln zł (ok. 62,77\% łącznej wartości inwestycji). W ramach projektów hybrydowych 3 z 19 przedsięwzięć sa na etapie przed zawarciem umowy o dofinansowanie z środków UE (wartość projektów razem wynosi: 285,63 mln zł - 7,02\% wartości wszystkich projektów, z kolei wartość planowanego dofinansowania: $214,53 \mathrm{mln} \mathrm{zł}-8,40 \%$ wartości dofinansowania wszystkich projektów). Projekty, dla których zostały zawarte umowy na koncesję lub PPP, stanowią 54,61\% łącznej wartości projektów (2221,84 mln zł - 9 z 19 inwestycji), przy czym wartość dofinansowania wynosi: 1262,42 mln zł (49,44\% wartości ogółem dofinansowania). Szczegółowy wykaz liczby umów zawartych w ramach partnerstwa publiczno-prywatnego oraz umów na dofinansowanie z środków unijnych lub pożyczki w latach 2009-2013 prezentuje wykres 1 .

Pierwszy projekt o strukturze hybrydowej, na który została zawarta umowa na koncesję, to: „Kompleks mineralnych basenów w Solcu-Zdroju” - 2009 r. - o wartości inwestycji wynoszącej: 19,83 mln zł i dofinansowania z UE w wartości: $6,80 \mathrm{mln}$ zł, choć umowę o dofinansowanie podpisano dopiero w 2011 r. W 2010 r. dla przedsięwzięcia „Budowa Wielkopolskiej Sieci Szerokopasmowej” po raz pierwszy w Polsce zawarto zarówno umowę PPP w trybie prawa zamówień publicznych (dialog konkurencyjny), jak i umowę na dofinansowanie z UE (wartość projektu: 407,11 mln zł, wartość dofinansowania: 283,64 mln zł), gdzie beneficjentem była spółka celowa powołana w formie spółki akcyjnej - w chwili obecnej projekt jest na etapie poszukiwania operatora w trybie koncesji. Spośród wszystkich projektów 3 są na etapie eksploatacji i zarządzania (wartość projektów: 119,90 mln zł - 2,95\% udziału w wartości wszystkich projektów razem - oraz wartość dofinansowania z UE: 81,30 mln zł). Największa ilość i wartość projektów pozostaje na etapach:

1) ogłoszenie na wybór partnera - 6 projektów o łącznej wartości: 1215,03 mln zł (udział w łącznej wartości wszystkich projektów: 29,87\%), przy dofinansowaniu z UE w wartości: 839,92 $\mathrm{mln}$ zł, w tym 1 projekt nie ma podpisanej umowy o dofinansowanie (Rozbudowa Szpitala św. Wincentego a'Paulo Sp. z o.o. w Gdyni w celu rozszerzenia usług medycznych z uwzględnieniem udziału partnera); 
Wykres 1

Liczba podpisanych umów w ramach partnerstwa publiczno-prywatnego oraz umów na dofinansowanie z UE lub pożyczkę w latach 2009-2013

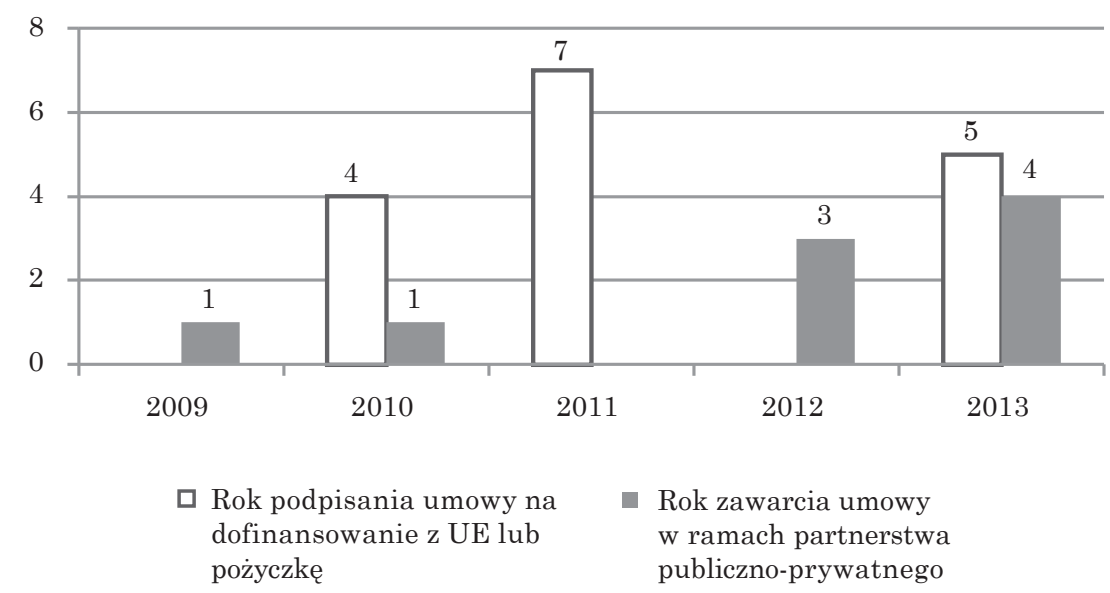

Źródło: opracowanie własne na podstawie Bazy Projektów Hybrydowych - październik 2013 (www. ppp.gov.pl).

2) realizacja (budowa) - 4 projekty o łącznej wartości: 1599,05 mln zł (udział w łącznej wartości wszystkich projektów: 39,31\%), przy dofinansowaniu z UE w wartości: 855,57 mln zł.

Przygotowany i realizowany projekt o największej skali przedsięwzięcia to: „System Gospodarki Odpadami dla Miasta Poznania”, gdzie wartość inwestycji wynosi: $757,83 \mathrm{mln}$ zł (18,63\% udziału w sumie wartości wszystkich projektów hybrydowych w latach 2009-2013), a wartość wsparcia finansowego ze strony funduszy strukturalnych (program POIiŚ) to: 352,00 $\mathrm{mln}$ zł (13,79\% wartości dofinansowania dla projektów łącznie). Z projektów, które można określić mianem „małych”, należy wyróżnić inwestycję „Kompleksowa termomodernizacja budynków oświatowych gminy Świdnica w formule partnerstwa publiczno-prywatnego" pozostajacy na etapie przed podpisaniem umowy o dofinansowanie. Z kolei wśród realizowanych wraz z umową na otrzymanie wsparcia z funduszu strukturalnego to: „Budowa stacji gazowej wysokiego ciśnienia, sieci gazowej średniego ciśnienia relacja Dębowa Łąka-Książki-Jabłonowo Pomorskie wraz z siecią rozdzielczą średniego ciśnienia na terenie gminy Książki i gminy Jabłonowo Pomorskie - Etap I" (wartość projektu: 7,72 mln zł, wartość dofinansowania z UE: 2,63 mln zł).

W tabeli 2 przedstawiono liczbę i wartość projektów hybrydowych oraz wartość dofinansowania z UE w ramach określonych programów według podziału na poszczególne województwa w Polsce w latach 2009-2013. 


\section{Tabela 2}

Liczba i wartość projektów hybrydowych oraz wartość dofinansowania z UE w ramach określonych programów według podziału na poszczególne województwa w Polsce w latach 2009-2013

\begin{tabular}{|c|c|c|c|c|c|c|}
\hline \multirow[t]{2}{*}{ Województwo } & \multirow[t]{2}{*}{$\begin{array}{l}\text { Wartość } \\
\text { projektu } \\
{[\mathrm{mln} \mathrm{zl}]}\end{array}$} & \multirow[t]{2}{*}{$\begin{array}{l}\text { Wartość } \\
\text { dofinanso- } \\
\text { wania z UE } \\
{[\mathrm{mln} \mathrm{zl}]}\end{array}$} & \multirow[t]{2}{*}{$\begin{array}{c}\text { Liczba } \\
\text { projektów }\end{array}$} & \multicolumn{3}{|c|}{$\begin{array}{c}\text { Wartość dofinansowanie } \\
\text { z określonego programu, } \\
\text { z jakiego pochodzą środki } \\
\text { z UE }\end{array}$} \\
\hline & & & & PO RPW & POIiŚ & RPO \\
\hline Dolnośląskie & 215,00 & 149,70 & 1 & - & - & 149,70 \\
\hline $\begin{array}{l}\text { Kujawsko- } \\
\text {-pomorskie }\end{array}$ & 15,86 & 5,41 & 2 & - & - & 5,41 \\
\hline Lubelskie & 385,08 & 266,97 & 1 & 266,97 & - & - \\
\hline Lubuskie & 1,31 & $1,29^{31}$ & 1 & - & - & 1,29 \\
\hline Małopolskie & 192,33 & 54,38 & 1 & - & - & 54,38 \\
\hline Mazowieckie & 493,34 & 340,94 & 1 & - & - & 340,94 \\
\hline Podkarpackie & 321,85 & 222,85 & 1 & 222,85 & - & - \\
\hline Podlaskie & 250,75 & 174,10 & 1 & 174,10 & - & - \\
\hline Pomorskie & 165,78 & $94,41^{32}$ & 2 & - & - & 94,41 \\
\hline Śląskie & 314,39 & $235,24^{33}$ & 3 & - & - & 235,24 \\
\hline Świętokrzyskie & 220,56 & 146,22 & 2 & 139,42 & - & 6,80 \\
\hline $\begin{array}{l}\text { Warmińsko- } \\
\text {-mazurskie }\end{array}$ & 327,04 & 226,34 & 1 & 226,34 & - & - \\
\hline Wielkopolskie & 1164,94 & 635,64 & 2 & - & 352,00 & 283,64 \\
\hline$\Sigma$ & 4068,23 & 2553,49 & 19 & 1029,68 & 352,00 & 1171,81 \\
\hline
\end{tabular}

Źródło: opracowanie własne na podstawie Bazy Projektów Hybrydowych - październik 2013 (www. ppp.gov.pl).

Na podstawie analizy danych w tabeli 2 dostrzega się, że nie we wszystkich województwach w Polsce podmioty publiczne uruchomiły projekty hybrydowe (13 z 16 województw). Największą wartość projektów obserwuje się w województwie wielkopolskim: $1164,94 \mathrm{mln}$ zł $(28,64 \%$ udziału w rynku polskich projektów hybrydowych w latach 2009-2013), co jest wynikiem realizacji naj-

${ }^{31}$ Planowana inwestycja „Kompleksowa termomodernizacja budynków oświatowych Gminy Świdnica w formule partnerstwa publiczno-prywatnego”, w ramach której nie zawarto umowy na dofinansowanie z środków UE. Wartość projektu: 1,31 mln zł. Wartość dofinansowania: 1,29 mln zł. Inwestycja została również ujęta w tabeli 3 i 4 oraz wykresach 1 i 2.

${ }^{32}$ Planowana inwestycja „Rozbudowa Szpitala św. Wincentego a'Paulo Sp. z o.o. w Gdyni w celu rozszerzenia usług medycznych z uwzględnieniem udziału partnera”, w ramach której nie zawarto umowy na dofinansowanie z środków UE. Wartość projektu: $70 \mathrm{mln}$ zł. Wartość dofinansowania: 52,50 mln zł. Inwestycja została również ujęta w tabeli 3 i 4 oraz wykresach 1 i 2.

${ }^{33}$ Planowana inwestycja „Budowa Centrum Przesiadkowego w Zabrzu”, w ramach której nie zawarto umowy na dofinansowanie z środków UE. Wartość projektu: 214,32 mln zł. Wartość dofinansowania: 160,74 mln zł. Inwestycja została również ujęta w tabeli 3 i 4 oraz wykresach 1 i 2. 
większego i jednego $\mathrm{z}$ większych projektów inwestycyjnych w formule PPP w Polsce. W ramach poszczególnych programów, z jakich pochodzą środki z UE, najwięcej pieniędzy wykorzystano z programu RPO (1171,81 mln zł w udziale wynoszącym 45,89\% wartości dofinansowania razem, w tym: 13 projektów) oraz programu PO RPW (1029,68 mln zł w udziale wynoszącym 40,32\% łącznej wartości dofinansowania - 5 projektów).

\section{Tabela 3}

Wartość projektów hybrydowych oraz wartość dofinansowania z UE w ramach określonych sektorów według podziału na poszczególne województwa w Polsce w latach 2009-2013

\begin{tabular}{|c|c|c|c|c|c|c|c|}
\hline \multirow[b]{2}{*}{ Województwo } & \multicolumn{7}{|c|}{ Sektor } \\
\hline & $\begin{array}{c}\text { efektyw- } \\
\text { ność ener- } \\
\text { getyczna }\end{array}$ & $\begin{array}{c}\text { gospodar- } \\
\text { ka odpa- } \\
\text { dami }\end{array}$ & innowacje & $\begin{array}{l}\text { ochrona } \\
\text { zdrowia }\end{array}$ & $\begin{array}{l}\text { rewitali- } \\
\text { zacja }\end{array}$ & $\begin{array}{l}\text { sport } \\
\text { i rekre- } \\
\text { acja }\end{array}$ & $\begin{array}{l}\text { telekomu- } \\
\text { nikacja }\end{array}$ \\
\hline Dolnośląskie & - & - & - & - & - & - & $\begin{array}{l}215,00 \\
149,70\end{array}$ \\
\hline $\begin{array}{l}\text { Kujawsko- } \\
\text {-pomorskie }\end{array}$ & $\begin{array}{r}15,86 \\
5,41 \\
\end{array}$ & - & - & - & - & - & - \\
\hline Lubelskie & - & - & - & - & - & - & $\begin{array}{l}385,08 \\
266,97\end{array}$ \\
\hline Lubuskie & $\begin{array}{l}1,31 \\
1,29 \\
\end{array}$ & - & - & - & - & - & \\
\hline Małopolskie & - & - & - & - & - & - & $\begin{array}{r}192,33 \\
54,38 \\
\end{array}$ \\
\hline Mazowieckie & - & - & - & - & - & - & $\begin{array}{l}493,34 \\
340.94\end{array}$ \\
\hline Podkarpackie & - & - & - & - & - & - & $\begin{array}{l}321,85 \\
222,85\end{array}$ \\
\hline Podlaskie & - & - & - & - & - & - & $\begin{array}{l}250,75 \\
174,10 \\
\end{array}$ \\
\hline Pomorskie & - & - & - & $\begin{array}{l}70,00 \\
52,50 \\
\end{array}$ & $\begin{array}{l}95,78 \\
41,91 \\
\end{array}$ & - & - \\
\hline Śląskie & - & - & $\begin{array}{l}38,75 \\
29,54 \\
\end{array}$ & - & $\begin{array}{l}214,32 \\
160,74 \\
\end{array}$ & $\begin{array}{l}61,32 \\
44,96 \\
\end{array}$ & - \\
\hline Świętokrzyskie & - & - & - & - & - & $\begin{array}{r}19,83 \\
6,80 \\
\end{array}$ & $\begin{array}{l}200,73 \\
139,42 \\
\end{array}$ \\
\hline $\begin{array}{l}\text { Warmińsko- } \\
\text {-mazurskie }\end{array}$ & - & - & - & - & - & - & $\begin{array}{l}327,04 \\
226,34\end{array}$ \\
\hline Wielkopolskie & - & $\begin{array}{l}757,83 \\
352,00\end{array}$ & - & - & - & - & $\begin{array}{l}407,11 \\
283,64\end{array}$ \\
\hline $\begin{array}{l}\text { Wartość } \\
\text { projektu } \sum \\
\text { Wartość } \\
\text { dofinans. } \sum\end{array}$ & $\begin{array}{r}17,17 \\
6,70 \\
\end{array}$ & $\begin{array}{l}757,83 \\
352,00\end{array}$ & $\begin{array}{l}38,75 \\
29,54 \\
\end{array}$ & $\begin{array}{r}70,00 \\
52,50 \\
\end{array}$ & $\begin{array}{l}310,10 \\
202,65 \\
\end{array}$ & $\begin{array}{l}81,15 \\
51,76 \\
\end{array}$ & $\begin{array}{l}2793,23 \\
1858,34 \\
\end{array}$ \\
\hline
\end{tabular}

Źródło: opracowanie własne na podstawie Bazy Projektów Hybrydowych - październik 2013 (www. ppp.gov.pl). 
W tabeli 3 zaprezentowano wartość projektów hybrydowych oraz wartość dofinansowania z UE w ramach określonych sektorów według podziału na poszczególne województwa w Polsce w latach 2009-2013. Uwzględniając informacje zawarte w tabeli 3, należy przyjąć, że czołowy sektor gospodarki, w ramach którego podejmowane sa inicjatywy współpracy sektora publicznego i prywatnego, to telekomunikacja i przedsięwzięcia związane przede wszystkim z rozbudową sieci szerokopasmowej. Łączna wartość tych projektów wynosi: 2793,23 mln zł (68,66\% wartości projektów hybrydowych łącznie), przy dofinansowaniu z środków unijnych w wartości: 1858,34 mln zł (72,78\% sumy wartości dofinansowania do wszystkich projektów).

Tabela $4 \mathrm{w}$ strukturze podobna do tabeli 3 prezentuje wartość projektów hybrydowych oraz wartość dofinansowania z UE w ramach określonych programów według podziału na poszczególne sektory w latach 2009-2013.

Tabela 4

Wartość projektów hybrydowych oraz wartość dofinansowania z UE w ramach określonych programów według podziału na poszczególne sektory w latach 2009-2013

\begin{tabular}{|c|c|c|c|c|c|c|c|}
\hline \multirow[b]{2}{*}{ Program } & \multicolumn{7}{|c|}{ Sektor } \\
\hline & $\begin{array}{l}\text { efektywność } \\
\text { energetyczna }\end{array}$ & $\begin{array}{c}\text { gospodarka } \\
\text { odpadami }\end{array}$ & $\begin{array}{c}\text { innowa- } \\
\text { cje }\end{array}$ & $\begin{array}{l}\text { ochrona } \\
\text { zdrowia }\end{array}$ & $\begin{array}{c}\text { rewitali- } \\
\text { zacja }\end{array}$ & $\begin{array}{c}\text { sport } \\
\text { i rekreacja }\end{array}$ & $\begin{array}{l}\text { telekomu- } \\
\text { nikacja }\end{array}$ \\
\hline PO RPW & & & & & & & $\begin{array}{l}1485,45 \\
1029,68 \\
\end{array}$ \\
\hline POIiŚ & & $\begin{array}{l}757,83 \\
352,00\end{array}$ & & & & & \\
\hline RPO & $\begin{array}{r}17,17 \\
6,70 \\
\end{array}$ & & $\begin{array}{l}38,75 \\
29,54\end{array}$ & $\begin{array}{l}70,00 \\
52,50\end{array}$ & $\begin{array}{l}310,10 \\
202,65\end{array}$ & $\begin{array}{l}81,15 \\
51,76\end{array}$ & $\begin{array}{r}1307,78 \\
828,66\end{array}$ \\
\hline $\begin{array}{l}\text { Wartość } \\
\text { projektu } \sum \\
\text { Wartość } \\
\text { dofinans. } \sum\end{array}$ & $\begin{array}{r}17,17 \\
6,70\end{array}$ & $\begin{array}{l}757,83 \\
352,00\end{array}$ & $\begin{array}{l}38,75 \\
29,54\end{array}$ & $\begin{array}{l}70,00 \\
52,50\end{array}$ & $\begin{array}{l}310,10 \\
202,65\end{array}$ & $\begin{array}{l}81,15 \\
51,76\end{array}$ & $\begin{array}{l}2793,23 \\
1858,34\end{array}$ \\
\hline
\end{tabular}

Źródło: opracowanie własne na podstawie Bazy Projektów Hybrydowych - październik 2013 (www. ppp.gov.pl).

$\mathrm{Na}$ podstawie tabeli 4 widać, że najintensywniej wykorzystywano przy realizacji projektów hybrydowych dotacje z programu RPO (wszystkie sektory z wyjątkiem gospodarki odpadami). Z kolei ogromne przedsięwzięcia inwestycyjne w zakresie sektora telekomunikacji (budowa sieci szerokopasmowych) były przeprowadzane z wykorzystaniem środków z UE pochodzących z programów PO RPW (wartość projektów: 1485,85 mln zł, co stanowi 36,51\% wartości projektów ogółem oraz wartość dofinansowania z UE: 1029,68 mln zł) i RPO (wartość projektów: 1307,78 mln zł - 36,51\% łącznej wartości projektów oraz wartość dofinansowania z UE: 828,66 mln zł). 
Na wykresie 2 uzupełniająco przedstawiono udział wartości projektów hybrydowych poszczególnych beneficjentów środków z UE według podziału na formy prawne podmiotu w latach 2009-2013. Na podstawie wykresu widać, iż wśród beneficjentów podejmujących inwestycje w formule PPP największą aktywność wykazują urzędy marszałkowskie (6 projektów hybrydowych o łącznej wartości: 1700,45 mln zł - 41,80\% udział w wartości projektów ogółem, przy dofinansowaniu z UE w wartości: 1179,38 mln zł) oraz miasta na prawach powiatu (5 projektów hybrydowych o łącznej wartości: 1168,00 mln zł - 28,71\% sumy wartości projektów - i dofinansowaniu z UE w wartości: $629,15 \mathrm{mln}$ zł), a więc podmioty publiczne o rozbudowanej strukturze organizacyjnej i wyposażone w szeroką kadrę pracowników pod względem wiedzy, $\mathrm{w}$ tym wiedzy specjalistycznej i doświadczenia.

\section{Wykres 2}

Udział wartości projektów hybrydowych poszczególnych beneficjentów środków z UE według podziału na formy prawne podmiotu w latach 2009-2013

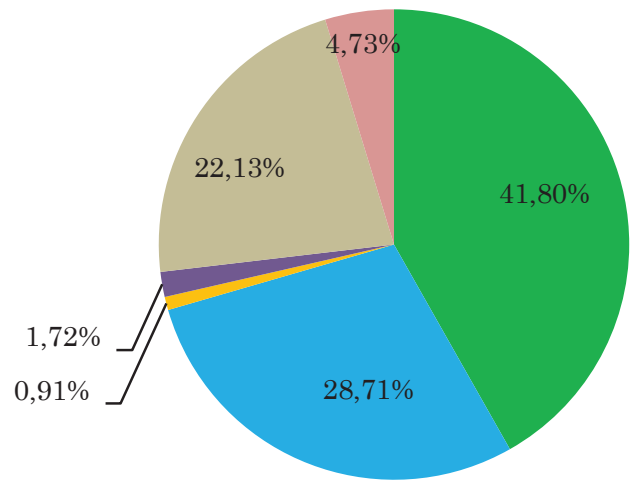

- Urząd Marszałkowki

Miasto na prawach powiatu

Gmina

- Miasto na prawach powiatu / Spółka akcyjna

- Spółka akcyjna

- Spółka z o.o.

Źródło: opracowanie własne na podstawie Bazy Projektów Hybrydowych - październik 2013 (www. ppp.gov.pl).

Ocena ilości projektów hybrydowych realizowanych w Polsce w ostatnich latach, począwszy od pierwotnej ustawy o PPP z 2005 r. - w kontekście istniejących uwarunkowań gospodarczych po 2007 r., a mianowicie intensyfikacji inwestycji realizowanych przez sektor publiczny, wynikająca m.in. z perspektywy finansowej pozyskania środków z budżetu Unii Europejskiej w latach 2007-2013 czy też przygotowania infrastruktury w celu jej dostosowania do potrzeb zorganizowania imprezy o randze międzynarodowej (EURO 2012), jak również uwzględnianie kierunków rozwoju PPP pod względem kategorii sektorów (w szczególności branża telekomunikacyjna, i to w ostatnich 2-3 latach) pozwalają uznać, że zdecydowanie za mało przedsięwzięć było podejmowanych $\mathrm{w}$ formule partnerstwa publiczno-prywatnego, choćby w celu znacznie sku- 
teczniejszego i efektywniejszego wykorzystania środków pomocowych z UE przy niższej wartości zadłużenia sektora publicznego, w szczególności samorządów terytorialnych.

\section{STRATEGIA ROZWOJU I EWALUACJI PPP W PERSPEKTYWIE FINANSOWEJ 2014-2020}

Z dniem 1 stycznia 2014 r. dla Polski oraz pozostałych państw należących do Unii Europejskiej rozpoczęła się nowa perspektywa prognoz finansowania projektów z wykorzystaniem środków strukturalnych w horyzoncie czasowym wyznaczonym ramami lat 2014-2020. Polsce w podziale budżetu UE przypadła do konsumpcji ilość środków na poziomie zbliżonym do okresu 2007 2013. Negocjacje przedstawicieli rządu Rzeczypospolitej umożliwiły osiagnąć ostateczne rozstrzygnięcia co do wielkości środków z UE, w przewidywanej wartości wynoszącej ok. 82,5 mld euro w odniesieniu do realizacji planowanej polityki spójności. Nowa perspektywa finansowania zakłada realizację projektów w szczególności w obszarach związanych z: badaniami naukowymi oraz ich komercjalizacja, rozwojem przedsiębiorczości, transparentnością istotnych połączeń drogowych (węzły autostrad, dróg ekspresowych), transportem przyjaznym środowisku (kolej i transport publiczny), cyfryzacją kraju (szerokopasmowy dostęp do Internetu - w trakcie realizacji na szeroka skalę, zob. „Projekty hybrydowe w Polsce w perspektywie finansowej 2007-2013”, e-usługi administracji), czy też włączeniem społecznym i aktywizacją zawodową ${ }^{34}$.

Dla sektora publicznego - samorządów terytorialnych - początek roku 2014 to także rozpoczęcie obowiązywania nowych przepisów w zakresie wykorzystywania indywidualnego wskaźnika zadłużenia samorząóo (art. 234 ustawy o finansach publicznych), stanowiącego limit możliwości zadłużenia się samorządów terytorialnych. Konstrukcja indywidualnego wskaźnika zadłużenia jest oparta na średniej arytmetycznej nadwyżki operacyjnej z ostatnich trzech lat. W założeniu wskaźnik ten ma na celu wspomóc samorządy $\mathrm{w}$ samodzielnym oddłużeniu się przy jednoczesnym zapewnieniu możliwości dalszego korzystania z funduszy unijnych, tym bardziej że nowa perspektywa finansowania z budżetu UE na lata 2014-2020 oznacza konieczność zaangażowania środków własnych, których samorządy nie posiadają w wielu wypadkach. Ważnym elementem ujętym w nowym prawodawstwie jest wyłączenie z wpływu na indywidualny wskaźnik zadłużenia obciążeń poniesionych po 1 stycznia 2013 r., wynikających z realizacji projektów współfinansowanych przez UE, co najmniej w $60 \%$.

Inwestycje w wymiarze niematerialnym lub rzeczowym z udziałem funduszy unijnych są kluczowym źródłem finansowania działań rozwojowych, w szczególności dla krajów rozwijających się UE, w tym również Polski, jednakże nie są możliwe bez dodatkowego zaangażowania krajowych środków publicznych. Ograniczony zasób środków publicznych oraz dostępności do ka-

${ }^{34}$ Zob. www.mir.gov.pl. 
pitału pochodzącego z zewnętrznych źródeł finansowania ze względu na poziom zadłużenia podmiotów wymuszają poszukiwanie alternatywnych modeli finansowania przedsięwzięć, także w celu pozyskania dofinansowania z środków budżetu UE i osiagnięcia efektu oczekiwanego przez interesariuszy.

Sytuacja ogólnogospodarcza w ostatnich latach spowodowała wśród podmiotów publicznych m.in. szczególne zainteresowanie partnerstwem publiczno-prywatnym w powiązaniu z finansowaniem projektów z środków Unii Europejskiej. Mechanizm lewarowania dotacji z Unii Europejskiej przez strumień środków finansowych pochodzaccych $\mathrm{z}$ sektora prywatnego w ramach partnerstwa publiczno-prywatnego jest kuszący dla państw członkowskich, biorąc pod uwagę ich aktualną sytuację ekonomiczna. Etap procesu konsultacji projektów rozporządzeń wyszczególniających ogólne warunki wykorzystywania funduszy UE2 (,fundusze unijne” lub „dotacje unijne”), w perspektywie programowania 2014-2020, stanowił doskonały moment na rozważenie i ustosunkowanie się do kwestii łączenia finansowania z sektora publicznego i prywatnego w ramach struktur PPP wraz dotacjami unijnymi ${ }^{35}$.

Temat dotyczący konieczności uwzględnienia regulacji w zakresie partnerstwa publiczno-prywatnego w ramowym rozporządzeniu Parlamentu Europejskiego i Rady ${ }^{36}$ wywołał dyskusję zainicjowana przez grupę roboczą ds. łączenia PPP z środkami UE, funkcjonującą w ramach Europejskiego Centrum Wiedzy PPP (EPEC). Pierwsze propozycje ujęcia w treści rozporządzenia zapisów dotyczących projektów hybrydowych pojawiły się na spotkaniu grupy już w grudniu 2011 r. Intensywne starania polskich negocjatorów pozwoliły przenieść rozważania obejmujace projekty hybrydowe na poziom grupy roboczej Rady Unii Europejskiej oraz ostatecznie zaktualizować projekt rozporządzenia przez wprowadzenie odrębnego rozdziału poświęconego projektom PPP, w tym projektom hybrydowym ${ }^{37}$.

Nowe elementy w postaci oddzielnych zapisów (odrębny rozdział), jakie pojawiły się w tego typu rozporządzeniu ogólnym, a obejmujące tematykę PPP, to w szczególności definicja partnerstwa publiczno-prywatnego oraz uznanie szczególnej specyfiki tych przedsięwzięć. Polska strona negocjacyjna przeprowadziła również skuteczne działania w zakresie finansowania z środków UE w perspektywie 2014-2020 m.in.:

1) uznanie możliwości finansowania z Europejskiego Funduszu Rozwoju Regionalnego budowy sieci przesyłowych oraz magazynów gazu i energii,

2) zagwarantowanie przeprowadzania rewitalizacji linii kolejowych i finansowania mieszkalnictwa z Funduszu Spójności (projekty zwiększające efektywność energetyczna),

${ }^{35}$ Fundusze unijne w PPP. Zestawienie projektów i studia przypadków, Wydawnictwo Europejskiego Centrum Wiedzy PPP, Warszawa 2012, s. 2 i 3.

${ }^{36}$ Rozporządzenie Parlamentu Europejskiego i Rady (UE) nr 1303/2013 z 17 grudnia 2013 r., Dz. Urz. UE z 20 grudnia 2013 r.

${ }^{37}$ Partnerstwo publiczno-prywatne w nowym okresie programowania (2014-2020). Komentarz do przepisów Rozporzqdzenia Ogólnego na lata 2014-2020 w zakresie partnerstwa publiczno-prywatnego, Ministerstwo Infrastruktury i Rozwoju, Departament Wsparcia Projektów Partnerstwa Publiczno-Prywatnego, Warszawa 2013, s. 4. 
3) określenie zasad wsparcia dla Mazowsza na poziomie zbliżonym do reguł obowiązujących w regionach mniej rozwiniętych,

4) finansowanie $z$ środków UE infrastruktury podstawowej w obszarze środowiska oraz transportu ${ }^{38}$.

Starania przedstawicieli polskiego rządu w fazie negocjacji z jednej strony miały na celu osiagnięcie największych korzyści dla państwa w perspektywie finansowej lat 2014-2020, z drugiej - były związane z dążeniem do zagwarantowania synergii postanowień władz Unii Europejskiej, co do wizji przyszłego rozwoju UE - z wieloletnimi ogólnymi planami rozwoju społeczno-gospodarczego Polski przyjętymi w trzech horyzontach czasowych: krótko-, średnio- i długookresowym. Wizja, misja, cele strategiczne i operacyjne, a także zadania i działania planowane przez rząd z postrzeganiem państwa za kilka i kilkadziesiąt lat zostały zawarte m.in. w dokumentach: „Polska 2030. Trzecia fala nowoczesności. Długookresowa Strategia Rozwoju Kraju” opracowana przez Ministerstwo Administracji i Cyfryzacji w 2013 r. oraz „Strategia Rozwoju Kraju 2020" zredagowana przez Ministerstwo Rozwoju Regionalnego w 2012 r., a także innych opracowaniach o charakterze strategicznym dla poszczególnych obszarów aktywności społeczno-gospodarczej (strategie zintegrowane oraz strategie poszczególnych województw).

W ramach tych dokumentów o wymiarze wieloletniej perspektywy rozwoju kraju poza kierunkami oddziaływania rządu na pobudzenie ewaluacji społeczno-gospodarczej Polski wskazuje się również m.in. na potrzebę modernizacji struktury wydatków publicznych. Restrukturyzacja portfela wydatków ma na celu pobudzenie i intensyfikację w obszarach: „[...] inwestycji publicznych, nakładów na naukę, badania, kulturę, zdrowie - przy zmniejszeniu skali transferów społecznych, co będzie mogło wynikać z większej samodzielności gospodarstw domowych, dzięki wzrostowi zatrudnienia”. Restrukturyzacja wydatków publicznych ma nie tylko objąć wymiar oszczędności środków finansowych, ale także dotyczyć wzrostu efektywności wydatków na różnego typu usługi dobra publicznego w wyniku lepszego ich kierowania do użytkowników oraz kontraktowania rynkowego przy jednoczesnym pomiarze skuteczności i efektywności podejmowanych działań. W sferze zarządzania sektorem publicznym niezwykle ważne będzie obniżanie kosztów oraz obciążeń budżetu. Modernizacja finansów publicznych, w tym wydatków, i kreowanie warunków dla większej akumulacji środków na rzecz potrzeb rozwoju i innowacji - zdaniem rządu - to czynniki niezbędne do osiągnięcia korzystniejszych warunków dla społeczeństwa, z kolei środki unijne same w sobie nie są i nie będą w przyszłości jedyną wystarczająca gwarancją rozwoju ${ }^{39}$.

W horyzoncie obecnej, jak i kolejnej dekady, do 2030 r. przedstawiciele społeczeństwa sprawujący władzę w państwie upatrują pozyskiwanie źródeł finansowania rozwoju o zdywersyfikowanym charakterze w kategoriach klucza do sukcesu osiągnięcia sformułowanych celów w warunkach kryzysu go-

\footnotetext{
${ }^{38}$ Negocjacje ram prawnych polityki spójności, co udało się osiagnać?, Informacja Prasowa Ministerstwa Rozwoju Regionalnego, Warszawa 2012, s. 2 i 3.

${ }^{39}$ Polska 2030. Trzecia fala nowoczesności. Dtugookresowa Strategia Rozwoju Kraju, Ministerstwo Administracji i Cyfryzacji, Warszawa 2013, s. 67.
} 
spodarczego oraz problemów strefy euro. W treści opracowania pt.: „Polska 2030. Trzecia fala nowoczesności. Długookresowa Strategia Rozwoju Kraju” można znaleźć zapisy wprost definiujące niezwykle ważną pozycję i rolę partnerstwa publiczno-prywatnego w perspektywie inwestycji przyszłości i rozwoju Polski; np. „Istotne będzie rozwinięcie na szeroką skalę formuły PPP, czy rosnąca rola rynku kapitałowego i jego różnorodności (np. rynek obligacji przedsiębiorstw, obligacje infrastrukturalne podmiotów i funduszy prywatnych, czy nowe narzędzia finansowe związane ze wsparciem długoterminowych kredytów hipotecznych)"

Jeden z strategicznych kierunków interwencji państwa koncentrujących się na zwiększeniu: „[...] dostępności powszechnych programów kształtowania postaw przedsiębiorczych i wspieraniu przedsiębiorczości, opartej o postawy proinnowacyjne, kreatywne, umiejętność współpracy”- cel nr 4 pt. „Wzrost wydajności i konkurencyjności gospodarki” - podnosi jako działanie priorytetowe do progresywnej realizacji przedsięwzięć $\mathrm{w}$ formule partnerstwa publiczno-prywatnego, czy publiczno-społecznego oraz replikacji tzw. dobrych praktyk w tym zakresie w szczególności w obszarze pobudzania przedsiębiorców do uczestnictwa w tego typu projektach ${ }^{41}$.

Opracowanie strategiczne pt. „Strategia Rozwoju Kraju 2020” obejmujace horyzontem czasowym obecną dekadę, tj. do 2020 r., podkreśla, iż: „Niezbędne jest funkcjonowanie w większej niż dotychczas skali partnerstw publiczno-prywatnych" ${ }^{\prime 2}$. W tym dokumencie zwraca się również uwagę na zdywersyfikowanie źródeł finansowania rozwoju przy ograniczonych środkach budżetowych przez większe wykorzystanie partnerstwa publiczno-prywatnego równolegle do środków unijnych i bezpośrednich inwestycji zagranicznych. Ważna pozostaje także aktywizacja: ,[...] sektora prywatnego w zakresie współpracy i współodpowiedzialności za bezpieczne otoczenie we wszystkich sferach działalności gospodarczej i publicznej”. Promocja i upowszechnienie wykorzystania instrumentu PPP obejmuje wszystkie strategie zintegrowane wraz z strategiami województw na lata 2012-2015 i 2016-2020 (Cel I.2.3. „Zwiększenie wykorzystania środków pozabudżetowych") ${ }^{43}$.

Idee rozwoju partnerstwa publiczno-prywatnego w strategii rozwoju kraju do 2020 r. zostały zdefiniowane bezpośrednio w obszarach inwestycji w infrastrukturę transportową (Cel II.7.1. „Zwiększenie efektywności zarządzania w sektorze transportowym”) oraz prace badawczo-rozwojowe, tzw. „B+R” (Cel II.3.1. „Wzrost popytu na wyniki badań naukowych”). Podnoszona jest waga mechanizmu PPP w kwestii alternatywnego źródła finansowania inwestycji oraz zwiększenia efektywności zarządzania projektami infrastrukturalnymi (terminowa finalizacja inwestycji i właściwy podział ryzyka) ${ }^{44}$. W perspektywie długoterminowej wzrost zainteresowania innowacyjnością oddziałujacca na rozwój, związaną przede wszystkim z pracami $\mathrm{B}+\mathrm{R}$, będzie upowszechnia-

\footnotetext{
40 Ibidem, s. 67 i 68.

${ }^{41}$ Ibidem, s. 89.

42 Strategia Rozwoju Kraju 2020, Ministerstwo Rozwoju Regionalnego, Warszawa 2012, s. 18.

43 Ibidem, s. 53.

44 Ibidem, s. 137.
} 
ny wśród przedsiębiorstw, m.in. przez: instrumenty gwarancyjne, komercjalizację wyników badań naukowych czy zmianę mechanizmów funkcjonowania oraz finansowania instytucji badawczych, wykorzystując do tego celu także potencjał zagregowany $\mathrm{w}$ formule partnerstwa publiczno-prywatnego ${ }^{45}$.

W dokumencie „Strategia Rozwoju Kraju 2020” rząd wskazał wprost na istotę działań wpływających na rozwój PPP w Polsce, tj. „Ważną rolę w finansowaniu szeroko rozumianego rozwoju kraju odgrywać będą prywatne podmioty gospodarcze dzięki inwestycjom własnym. Istotnym instrumentem właczania inicjatyw prywatnych w nurt działań rozwojowych kraju będzie, mało wykorzystywane dotychczas, partnerstwo publiczno-prywatne. W tym zakresie konieczne będzie uproszczenie mechanizmów i warunków funkcjonowania tego instrumentu" 46 .

Wskazywane kilkakrotnie w ramach tego artykułu Rozporzadzenie Parlamentu Europejskiego i Rady (UE) nr 1303/2013 z 17 grudnia 2013 r., opublikowane w „Dzienniku Urzędowym Unii Europejskiej” 20 grudnia 2013 r., wyznacza ramy projektów hybrydowych, jednakże koncentruje się tylko na wybranych aspektach ich realizacji, stąd sprawna realizacja tego typu przedsięwzięć będzie de facto uzależniona od ukształtowania systemu wdrażania funduszy UE przez instytucje zarządzające oraz od tego, czy nie będą wprowadzały sztucznych barier na poziomie programów operacyjnych. W opozycji do samego rozporządzenia bardzo ważne pozostaje sformułowanie treści aktów delegowanych Komisji Europejskiej, o ile zostaną wprowadzone. Pojawienie się w sposób bezpośredni w dokumencie o randze rozporządzenia zapisów dotyczących projektów hybrydowych uznaje się za istotny krok w kierunku popularyzacji oraz zwiększenia, w jej konsekwencji, liczby projektów tego typu, a jednocześnie stanowi wyraźny znak dążenia do osiąnnięcia celów polityki spójności i innych polityk Unii Europejskiej wśród państw członkowskich ${ }^{47}$.

Kwestia projektów hybrydowych została również podniesiona w tekście rozporządzenia obejmującego tematykę tzw. dużych projektów. W szczególności ważne pozostaje zawarte ustępstwo w wypadku tego typu projektów w zakresie konieczności podpisania umowy PPP przez beneficjenta (podmiot publiczny) w terminie trzech lat od wydania decyzji Komisji Europejskiej dla dużego projektu (w wypadku tradycyjnych projektów beneficjent musi zawrzeć pierwszą umowę na roboty budowlane w terminie trzech lat od decyzji KE) ${ }^{48}$.

Równie istotne znaczenie dla realizacji projektów hybrydowych mają zapisy dotyczace stosowania zryczałtowanych procentowych stawek przychodów netto w projektach generujących przychód netto odnoszących się do określonych sektorów (podejście to daje możliwość odstapienia od konieczności indywidualnego szacowania poziomu dofinansowania na podstawie kalkulacji luki w finansowaniu projektu $)^{49}$.

\footnotetext{
45 Ibidem, s. 89 i 90

${ }^{46}$ Ibidem, s. 188.

47 Partnerstwo publiczno-prywatne..., s. 25.

48 Ibidem, s. 25.

${ }^{49}$ Ibidem, s. 25.
} 
Rozpoczęta perspektywa finansowa 2014-2020 pokłada ogromne oczekiwania $\mathrm{w}$ intensyfikacji projektów hybrydowych, przede wszystkim za sprawą nowych regulacji obejmujących ogólne zasady realizacji przedsięwzięć w układzie PPP z udziałem funduszy europejskich, a mianowicie w wyniku:

1) wprowadzenia definicji partnerstwa publiczno-prywatnego;

2) zagwarantowania nadrzędnej roli przepisów dotyczących PPP nad przepisami o charakterze ogólnym;

3) wdrożenia możliwości uzyskania statusu beneficjenta programu zarówno przez podmiot publiczny, jak i prywatny;

4) dopuszczenia możliwości zmiany beneficjenta w trakcie realizacji projektu;

5) wprowadzenia możliwości kwalifikowania wydatków poniesionych oraz opłaconych przez partnera prywatnego jako wydatki poniesione i sfinansowane przez beneficjenta, ujęte we wniosku o płatność, jednakże tylko pod warunkiem zawarcia umowy PPP;

6) umożliwienia dokonywania wpłat $z$ tytułu płatności na rzecz beneficjentów, odnoszacych się do wydatków ujętych we wniosku o płatność, na rachunek powierniczy założony na rzecz beneficjenta;

7) zmiany przepisów dotyczących projektów generujących dochód ${ }^{50}$.

Państwowa instytucja kontrolująca podmioty sektora publicznego, a mianowicie Najwyższa Izba Kontroli, podejmując się kontroli przedsięwzięć realizowanych w układzie partnerstwa publiczno-prywatnego, rozpoznała szereg newralgicznych czynników wpływających na ilość oraz jakość dotychczas przeprowadzanych projektów $\mathrm{w}$ tego typu formule, również z wykorzystaniem środków pochodzących z budżetu UE. W ramach zbiorczego opracowania wyników kontroli zwróciła szczególną uwagę na: potrzebę wprowadzenia mechanizmów pomocy dla podmiotów publicznych sprzyjających poprawie merytorycznej jakości przygotowywanych przedsięwzięć PPP (przede wszystkim w początkowej fazie rozwoju PPP), likwidację obowiązku sporządzania sprawozdań Rb-Z-PPP (identyfikuje wyłącznie przedsięwzięcia realizowane na podstawie ustawy o PPP), jak również oczekiwania wobec precyzyjnego zdefiniowania oraz określenia zakresu ryzyka (budowy, popytu i dostępności), wraz z doprecyzowaniem metodologii ich podziału między strony przedsięwzięcia $\mathrm{PPP}^{51}$. Opracowanie to zawiera wprost zdefiniowane propozycje zmian w zakresie uregulowań dotyczących ustawy o PPP, ustawy o koncesji oraz ustawy PZP, w celu niwelowania barier współpracy między sektorami publicznym i prywatnym wynikających z obowiązującego prawa, a w konsekwencji wzrostu zainteresowania oraz efektywności przedsięwzięć w formule PPP (strona 49 opracowania).

50 Zob. www.skarbnik.info.

51 Realizacja przedsięwzięć w systemie partnerstwa publiczno-prywatnego. Informacja o wynikach kontroli, Najwyższa Izba Kontroli, Warszawa 2013, s. 7 i 8. 


\section{PODSUMOWANIE}

Narastające wykorzystanie projektów o strukturze hybrydowej na potrzeby realizacji inwestycji, w założeniu z wykorzystaniem formuły PPP, bez wątpienia umożliwi przekierunkowanie w sektorze publicznym myślenia i pojmowania związanego z zawieraniem umów o charakterze układu partnerskiego z podmiotem prywatnym. W założeniu połączenie finansowania inwestycji z środków funduszy UE oraz kapitału rynku prywatnego ma na celu ukształtowanie podejścia nastawionego na efektywność i optymalizację rozwiązań organizacyjno-inwestycyjnych. Osiagnnięcie wysokiego poziomu świadomości i przekonania do idei prorozwojowych w pierwszej kolejności wymaga odejścia od interpretacji PPP jako instrumentu stanowiącego alternatywne źródło finansowania przedsięwzięcia (struktura PPP przy założeniu transferu przeważającej ilości ryzyka na podmiot prywatny gwarantuje wyłączenie tego źródła finansowania w ramach budżetu podmiotu publicznego).

Biorąc pod uwagę świadomość władzy państwowej uzewnętrznioną w opracowaniach strategicznych oraz deklaracje popierania istoty partnerstwa publiczno-prywatnego, jako jednego z czynników dającego możliwość osiagnięcia założonych celów rozwoju otoczenia społeczno-gospodarczego Polski, należy uznać, że w perspektywie finansowej 2014-2020 formuła PPP, w szczególności w powiązaniu z środkami z Unii Europejskiej, będzie najbardziej pożądanym instrumentem realizacji przedsięwzięć, w tym przedsięwzięć o transparentności w skali makro (regionu, problemu, infrastruktury itd.). Skuteczne wdrożenie upowszechnienia się przedsięwzięć nie tylko w strukturze partnerstwa publiczno-prywatnego, lecz także z udziałem środków europejskich zobowiązuje rząd do podjęcia konkretnych działań związanych m.in. z: harmonizacja krajowej legislacji z rozwiazaniami proponowanymi przez UE, uwzględnieniem problematyki projektów hybrydowych w wytycznych dotyczących projektów generujacych dochód, publikacja przewodników i opracowań prezentujących ścieżkę postępowania i dobre praktyki w zakresie projektów hybrydowych.

Należy pamiętać, z jak ogromną rezerwą podmioty sektora publicznego i prywatnego podchodziły do wykorzystywania dotacji unijnych przy realizacji projektów w pierwszej fazie perspektywy finansowej 2007-2013 i jak narastała tendencja wzrostu w tym zakresie. Przenoszac to na obszar przedsięwzięć w układzie PPP (w tym projektów hybrydowych i ich intensyfikację od 2009 r.), wartość dodaną w postaci uregulowań na poziomie prawa wspólnotowego Unii Europejskiej w nowej perspektywie finansowania na lata 2014-2020, można upatrywać optymistycznie szans na rozwój tej formuły. Niezwykle ważna pozostanie w tej kwestii postawa rządu, która nie powinna okazać się zaledwie pustymi hasłami politycznymi i zapisami w opracowaniach strategicznych, ale rzetelnie wdrożoną polityką ekonomiczna. W pierwszej kolejności ważne jest osiagnięcie tzw. fazy dojrzałości (odpowiednich warunków otoczenia rozwoju formuły PPP, np. dojrzałość podmiotów sektora publicznego i prywatnego, warunki gospodarcze, procesy propagowania projektów w modelu PPP itd.) $\mathrm{w}$ realizacji przedsięwzięć w strukturze partnerstwa publiczno-prywatnego, 
jednakże jej stworzenie nie jest i nie będzie możliwe dopóty, dopóki rząd nie wyznaczy lub nie wyodrębni podmiotu odpowiedzialnego za opracowanie i wdrożenie polityki budowania otoczenia dla intensyfikacji przedsięwzięć w układzie PPP. Delegowanie podmiotu odpowiedzialnego za realizację to pierwszy z ważnych kroków na ścieżce pobudzania i rozwoju kooperacji sektora publicznego z prywatnym. Istotne w procesie upowszechniania partnerskiej idei działania państwa (rządu i samorządów) wraz z podmiotami sektora prywatnego dla realizacji wspólnej polityki przyszłości Polski jest wypracowanie spójnych, czytelnych i równych dla wszystkich stron ram dających gwarancje wzajemnego bezpieczeństwa współpracy, w tym m.in. w postaci prawodawstwa oraz prezentacji tzw. dobrych praktyk gospodarczych.

mgr Bartosz Edwarczyk

Uniwersytet Ekonomiczny w Poznaniu

bartosz.edwarczyk@phd.ue.poznan.pl

HYBRID PROJECTS AT THE THRESHOLD OF FINANCIAL PERSPECTIVE 2014-2020

Summary

The purpose of this article is to present, on the one hand, the synthetic issues arising from the implementation of projects in the public-private partnership (PPP) formula in conjunction with financing from the European Union in Poland, and, on the other hand, the state policy regarding the development and evaluation of projects of hybrid structure in the new financial perspective for 2014-2020. The importantce of achieving added value resulting from the implementation of an investment in the public-private partnership model is stressed, in particular in a situation of a constant deficit of resources and the rising expectations of stakeholders. Special attention is paid to the prevailing economic downturn being a result of the crisis and the increasing indebtedness of the public sector in the context of the possibility of obtaining funds from the EU budget for the period 2014-2020.

The legal and organisational space lying at the basis of the PPP is also being examined in the context of the European Union regulation and national solutions. Another section of the article is devoted to a general analysis of hybrid projects that had been conducted in Poland until the end of 2013. An attempt was made to present in a concise manner the main and most significant provisions adopted in response to the outlined state policy in the area of promoting projects in the system of cooperation between sectors (public and private), connecting the present cooperation with additional funding in order to leverage investments. An attempt is also made to examine and evaluate possible future government actions undertaken to advance public-private partnerships, including hybrid projects. 
Copyright of Journal of Law, Economics and Sociology is the property of Faculty of Law and Administration of Adam Mickiewicz University in Poznan and its content may not be copied or emailed to multiple sites or posted to a listserv without the copyright holder's express written permission. However, users may print, download, or email articles for individual use.

Właścicielem praw autorskich do „Ruchu Prawniczego, Ekonomicznego i Socjologicznego” jest Wydział Prawa i Administracji Uniwersytetu im. Adama Mickiewicza w Poznaniu. Zawartość czasopisma nie może być kopiowana, przesyłana do innych stron internetowych bądź zamieszczana na blogach bez pisemnej zgody wydawcy. Niemniej artykuły można drukować, kopiować lub przesyłać w formie elektronicznej na własny użytek. 